\title{
The Gene for a Novel Epidermal Antigen Maps near the Neurofibromatosis 1 Gene
}

\author{
lucille M. Kayes, ${ }^{*}$ Wanda T. Schroeder, $\dagger \neq$ Douglas A. Marchuk, $\S$ Francis $S$. Collins, $\S$

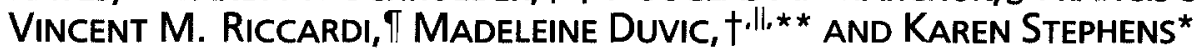 \\ "Division of Medical Genetics, Department of Medicine, University of Washington School of Medicine, Seattle, Washington; \\ Departments of $\dagger$ Dermatology, $¥$ Pharmacology, and "Internal Medicine, the University of Texas Medical School \\ and the ${ }^{* *} M$. D. Anderson Cancer Center, Houston, Texas; §Departments of Human Genetics and Internal Medicine \\ and the Howard Hughes Medical Institute, The University of Michigan Medical Center, Ann Arbor, Michigan; \\ and TThe Neurofibromatosis Institute Inc., Pasadena, California
}

Received March 13, 1992; revised July 10, 1992

\begin{abstract}
Recently the M17S1 gene, encoding an epidermal antigen thought to play a role in cell adhesion, was mapped to chromosome bands 17q11-q12, placing it in the vicinity of the gene for the genetic disorder neurofibromatosis 1 (NF1). The pleomorphic cutaneous lesions of NF1 and the precedent for other genes being embedded within the NF1 gene prompted us to investigate whether the M17S1 gene mapped near, or within, the NF1 gene. Genetic linkage analyses revealed that M17S1 was tightly linked to NF1 and mapped within the interval bounded by D17S58 and D17S54. Physical mapping of an M17S1 cDNA on somatic cell hybrids, yeast artificial chromosomes, and an NF1 patient with a deletion involving an entire NF1 allele demonstrated that $\mathrm{M17S1}$ is located at least $180 \mathrm{~kb}$ centromeric to the NF1 gene. The distance between the genes suggests that M17S1 is unlikely to contribute to the NF1 phenotype since a gross chromosomal rearrangement would be required to disrupt expression of both genes. (c) 1992 Academic Press, Inc.
\end{abstract}

\section{INTRODUCTION}

The epidermis is composed of keratinocytes that are continually differentiating and being pushed upward from the mitotic basal layer at the dermal-epidermal junction to the outer surface of the skin. The identification and study of differentiation-specific gene products has been a valuable strategy for investigating the structure, composition, and function of normal skin and the pathobiology of skin disorders (Fuchs, 1990; Fine et al., 1991). Several years ago, a $35-\mathrm{kDa}$ human epidermal protein was identified by the murine monoclonal antibody ECS-1 isolated from a mouse injected with cultured human foreskin keratinocytes (Negi et al., 1986). The ECS-1 antibody induced a complement-enhanced epidermal cell detachment activity suggesting that the 35 $\mathrm{kDa}$ protein may play a role in cell adhesion (Negi et al.,
1986). The cDNA encoding the $35-\mathrm{kDa}$ protein, named ESA for epidermal surface antigen, was recently cloned, and the DNA sequence predicted a peptide of 290 amino acids in length. The cloning, sequence, and tissue-specific expression of ESA will be reported elsewhere (W. Schroeder, unpublished data).

The ESA gene, designated M17S1, was mapped by in situ hybridization to human chromosome bands 17q11q12 (Schroeder et al., 1991). We found it intriguing that M17S1 was located in the vicinity of the gene for neurofibromatosis 1 , a disorder with multiple skin manifestations, located at 17q11.2 (Schmidt et al., 1987; Ledbetter et al., 1989). Neurofibromatosis 1 (NF1) is a common autosomal dominant genetic disorder affecting 1 of 3000 individuals (Crowe et al., 1956). The skin manifestations include cutaneous and subcutaneous neurofibromas, café-au-lait spots (hyperpigmented skin patches), and freckling in the armpit and groin. Neurofibromas can also be of the plexiform type, affecting a bundle(s) of nerves; hyperpigmentation and hypertrichosis (excessive hair) of the skin overlying the tumor are common. In addition to the skin manifestations, Lisch nodules of the iris, optic glioma, and certain bony abnormalities are diagnostic features of NF1. Affected individuals commonly have associated findings such as macrocephaly, scoliosis, learning disabilities, and increased risk of malignancy. Reviews of the clinical presentation of NF1 have been published (Riccardi, 1992; Stumpf et al., 1988; Rubenstein and Korf, 1990; Huson et al., 1989).

The NF1 gene is large and structurally complex. The gene, estimated at $300 \mathrm{~kb}$ in length, produces a transcript of approximately $13 \mathrm{~kb}$, and a predicted protein, designated neurofibromin, of 2818 amino acids (Wallace et al., 1990; Marchuk et al., 1991). During the search for the NF1 transcript, three small genes that mapped within a single large intron of the NF1 gene were identified, transcribed from the alternate strand (Cawthon et al., 1990a,b; O'Connell et al., 1990; Viskochil et al., 1991). Two of the embedded genes, EVI2A and EVI2B, are the 
human homologs of murine sequences where retroviral integration results in murine myeloid tumor expression (Buchberg et al., 1990). The third gene, oligodendrocyte-myelin glycoprotein (OMGP), is a component of unknown function of central nervous system myelin (Mikol and Stefansson, 1988).

The molecular bases for the inter- and intrafamilial variable expressivity that is a hallmark of the NF1 disorder have yet to be identified. A role of NF1 locus heterogeneity as a major contributory factor to interfamilial variability appears unlikely. Genetic linkage studies by an international consortium involving 142 multigenerational NF1 families support the hypothesis of a single NF1 gene in the pericentromeric region of chromosome 17 (summarized by Goldgar et al., 1989). Genetic linkage data and direct molecular identification of NF1 gene mutations indicated that the same gene was responsible for both familial and sporadic cases of the disorder (Stephens et al., 1987; Upadhyaya et al., 1990; Wallace et al., 1991; Kayes et al., 1992). This is an important observation since approximately $50 \%$ of cases are due to apparent new mutation in the NF1 gene (Crowe et al., 1956; Riccardi, 1992). It has been proposed that mutations disrupting an embedded gene, in addition to the NF1 gene, may contribute to interfamilial variability (Wallace et al., 1990; Cawthon et al., 1990a). However, screening the three known embedded genes of NF1 patients for mutations has been unproductive (O'Connell et al., 1990; Cawthon et al., 1990b, 1991; Viskochil et al., 1991). It remains to be determined whether any genes embedded in, or adjacent to, the NF1 gene contribute to the variable phenotype.

The skin manifestations and variable expressivity of the NF1 disorder and the precedent for other genes mapping within the NF1 gene prompted us to determine whether the M17S1 gene mapped near, or within, the NF1 gene.

\section{MATERIALS AND METHODS}

Families and DNA markers. Previously, we constructed a genetic map of eight loci in the pericentromeric region of chromosome 17 using data collected on 50 NF1 families (Stephens et al., 1987, 1989). The markers, with locus designations in parentheses, included p17H8 (D17Z1), A10-41 (D17S71), pEW301 (D17S58), pEW206 (D17S57), pEW207 (D17S73), pEW203 (D17S54), L581 (D17S37), and L946 (D17S36). For the current study, we chose 18 families with individuals previously determined to have a recombination event in the chromosome 17 pericentromeric region (Stephens et al., 1989); these families were BAY8, BAY13, BAY14, BAY17, BAY21, BAY25, BAY28, BAY31, BAY34, BAY35, BAY40, BAY45, BAY58, BAY77, BAY78, UMI4, UMI5, and UMI16. Family prefixes, designating the institution where the families were ascertained, are as established previously by the NF1 international genetic linkage consortium (Stephens et al., 1987, 1989; Goldgar et al., 1989). Accordingly, NF1 patients/families ascertained at the University of Washington are designated with the UWA prefix. In this study, these 18 families were typed with seven additional probe/enzyme systems (locus designations in parentheses) including pESA2-PstI (M17S1; W. Schroeder, unpublished data), pVAW210M2-MspI (D17S115), pVAW212-PstI (D17S117), p $38-2-$

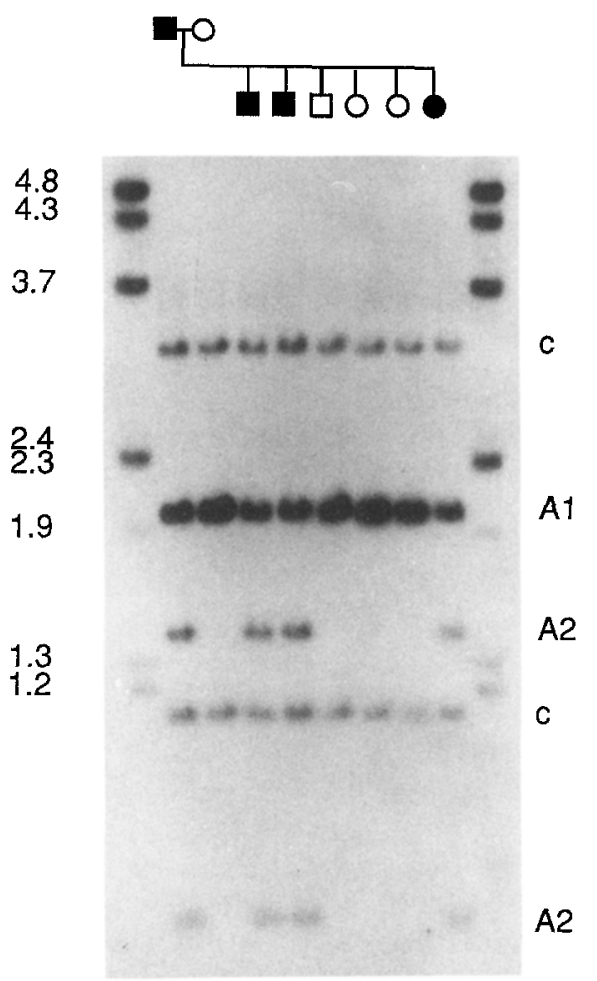

FIG. 1. Inheritance of a RFLP detected by M17S1 gene. Southern blot of PstI-digested DNA from individuals of family UMI4 hybridized with pESA2. The pedigree position and affected status for each family member is given above the appropriate lane. Solid symbols, NF1-affected individuals; open symbols, unaffected individuals; squares, male; circles, female. A1 and A2 indicate the two alleles; c designates invariant fragments. The outer lanes contain DNA size standards; sizes are given in kilobasepairs.

MspI (CRYB1; $\beta$-crystallin gene), pVAW215R3-TaqI (D17S120) (Fain et al., 1989), pHHH202-RsaI (D17S33; White et al., 1987), and pTH17.19-BglII (D17S82; O'Connell et al., 1989). pESA2 is a 2.0-kb partial cDNA of M17S1. Two NF1 cDNAs were used in the YAC studies; GE2 is a partial cDNA from the $5^{\prime}$ end, and P5 is a partial cDNA from the $3^{\prime}$ end of the gene (Wallace et al., 1990; Marchuk et al., 1991).

Somatic cell hybrids, cell lines, and YACs. DCR-1 and NF13 are human-mouse somatic cell hybrids carrying human derivative chromosomes from two unrelated NF1 patients with translocation breakpoints within the NF1 gene. DCR-1 has a derivative chromosome 1 (1qter-p34.3::17q11-qter; Schmidt et al., 1987; Menon et al., 1989) and NF13 a derivative chromosome 22 (22pter-22q11.2::17q11.217qter; Ledbetter et al., 1989). The NF13 breakpoint maps approximately $60 \mathrm{~kb}$ q-distal to the DCR-1 breakpoint (O'Connell et al., 1990). The SP3-10 hybrid contains a human derivative chromosome 15 (15pter-q22::17q11-17qter; Sheer et al., 1983, 1985). MH22.6 carries an intact chromosome 17 as its only human genomic component (van Tuinen et al., 1987). The LMTk ${ }^{-}$mouse cell line was the fusionrecipient for construction of DCR-1, NF13, and MH22.6 (van Tuinen et al., 1987). Cell lines were obtained from the American Type Culture Collection (Rockville, MD). UWA106-3 is an immortalized lymphoblastoid cell line from an NF1 patient with an extensive deletion encompassing the entire NF1 paternal allele and four flanking loci including D17S120, D17S115, D17S57, and D17S73 (Kayes et al., 1992). The three overlapping yeast artificial chromosome (YAC) clones A43A9, D8F4, and A113D7 form a contig that spans the NF1 gene (Marchuk et al., 1992). DNA from non-YAC-bearing yeast was a gift of Lee Hartwell.

DNA hybridization. Genomic DNA was purified from peripheral blood, immortalized lymphoblastoid cell lines, somatic cell hybrids 
TABLE 1

Pairwise Lod Scores for M17S1 and Chromosome 17 Loci

\begin{tabular}{|c|c|c|c|c|c|c|c|c|c|c|}
\hline \multirow[b]{2}{*}{ Locus } & \multicolumn{8}{|c|}{ Lod Score at $\theta$ of } & \multirow[b]{2}{*}{$\hat{\theta}$} & \multirow[b]{2}{*}{$\hat{z}$} \\
\hline & 0.001 & 0.01 & 0.05 & 0.10 & 0.20 & 0.30 & 0.40 & 0.50 & & \\
\hline NF1 & 6.61 & 6.49 & 5.96 & 5.27 & 3.82 & 2.31 & 0.90 & 0.00 & 0.00 & 6.62 \\
\hline D17S57 & 3.60 & 3.53 & 3.17 & 2.73 & 1.82 & 0.96 & 0.28 & 0.00 & 0.00 & 3.61 \\
\hline D17S73 & 3.30 & 3.24 & 2.96 & 2.59 & 1.83 & 1.08 & 0.42 & 0.00 & 0.00 & 3.31 \\
\hline D17S54 & 0.31 & 2.19 & 3.04 & 2.95 & 2.17 & 1.23 & 0.39 & 0.00 & 0.06 & 3.06 \\
\hline D17S71 & 2.67 & 2.61 & 2.37 & 2.05 & 1.40 & 0.76 & 0.22 & 0.00 & 0.00 & 2.67 \\
\hline D17S120 & 2.40 & 2.36 & 2.19 & 1.96 & 1.47 & 0.95 & 0.43 & 0.00 & 0.00 & 2.41 \\
\hline D17S37 & 0.30 & 1.24 & 1.66 & 1.60 & 1.16 & 0.63 & 0.18 & 0.00 & 0.06 & 1.67 \\
\hline D17Z1 & 0.01 & 0.96 & 1.44 & 1.47 & 1.18 & 0.74 & 0.26 & 0.00 & 0.08 & 1.48 \\
\hline D17S115 & 0.90 & 0.89 & 0.81 & 0.72 & 0.52 & 0.30 & 0.09 & 0.00 & 0.00 & 0.90 \\
\hline D17S117 & 0.90 & 0.88 & 0.79 & 0.68 & 0.45 & 0.23 & 0.07 & 0.00 & 0.00 & 0.90 \\
\hline D17S33 & 0.60 & 0.59 & 0.54 & 0.47 & 0.32 & 0.17 & 0.05 & 0.00 & 0.00 & 0.60 \\
\hline CRYB1 & 0.30 & 0.29 & 0.26 & 0.21 & 0.13 & 0.06 & 0.02 & 0.00 & 0.00 & 0.30 \\
\hline
\end{tabular}

Note. Pairwise lod scores calculated at $\theta_{\mathrm{m}}=\theta_{\mathrm{f}} ; \hat{z}$, maximum lod score, $\hat{\theta}$, recombination fraction at $\hat{z}$.

(Bell et al., 1981), or YAC-containing yeast (Sherman et al., 1986). Five micrograms of human genomic DNA or $13 \mu \mathrm{g}$ of DNA from hybrid cell lines was digested with restriction enzymes $(5 \mathrm{U} / \mu \mathrm{g}$; Boehringer-Mannheim, Indianapolis) according to the manufacturer's directions, with the exception of $T a q \mathrm{I}$ and $M s p I$, which were digested at $67^{\circ} \mathrm{C}$ and room temperature, respectively, to minimize partial digestion products (Donis-Keller et al., 1987). The extent of the digestion was assessed in a second parallel test reaction (Schumm et $a l ., 1988)$ : a volume $(6 \mu \mathrm{l})$ of the original digestion reaction, containing $1 \mu \mathrm{g}$ of human DNA, was added to $1 \mu \mathrm{g} \lambda$ DNA. Complete digestion was assumed if the $\lambda$ DNA digest appeared complete upon ethidium bromide staining after agarose gel electrophoresis of the test reactions. Any original DNA-digested samples that were judged as incomplete were redigested with 2-5 U/ $\mu$ g DNA for 8-12 h. Digested samples were electrophoresed through $0.8 \%$ agarose at $1.7 \mathrm{~V} / \mathrm{cm}$ for $24-30$ h. Gels were denatured $30 \mathrm{~min}$ in $0.5 \mathrm{M} \mathrm{NaOH}$ and $1.5 M \mathrm{NaCl}$ and transferred overnight by capillary action to Zetabind membrane (AMF Cuno, Meriden, CT). For detection of restriction fragment length polymorphisms (RFLPs), cloned human DNA inserts were labeled in situ with their vector sequences by primer extension (Feinberg and Vogelstein, 1983). For hybridization to membranes with NF1-YAC DNAs, which carry plasmid sequences homologous to many of the probes, the human DNA insert was isolated from the probe vector by restriction enzyme digestion, electrophoresis, and recovery on NA45 DEAE membrane (Schleicher and Schuell, Keene, NH) before labeling. Hybridization was as previously described (Donis-Keller et al., 1987).

The copy number of the M17S1 gene in deletion patient UWA106-3 was assayed by densitometry. A Southern blot membrane with DNA from UWA106-3 and unrelated, non-NF individuals was sequentially hybridized to M17S1 and L946. L946 (Donis-Keller et al., 1987) was chosen to control for variation in DNA concentration among the sample lanes because it lies outside the deleted region of UWA106-3 (Kayes et al., 1992) and hybridizes to fragments of similar size as M17S1. The resulting autoradiograms were scanned with a Hoefer GS300 densitometer and Macintosh II computer. The density ratio of the 3.1-kb invariant band revealed by M17S1 (Fig. 3B) to the density of the 2.4-kb invariant band revealed by $\mathrm{L} 946$ (Fig. 3C) was determined for the control individual in Figs. $3 \mathrm{~B}$ and $3 \mathrm{C}$, lane 3 , and UWA106-3, Figs. 3B and 3C, lane 4.

Linkage analysis. Two-point and multipoint linkage analyses were performed with the program CRI-MAP Version 2.4 (P. Green, unpublished data; Barker et al., 1987; Donis-Keller et al., 1987). The ALL option of the program was used to calculate the likelihood that the M17S1 locus mapped in any one marker interval on a map of 15 peri- centromeric loci. The unique order of loci shown in Fig. 2 is based on genetic and physical data (Goldgar et al., 1989; Fain et al., 1989; Fountain et al., 1989); there are two ambiguities in locus order as summarized in Fig. 5. The CHROMPICS option of the program, which dis-

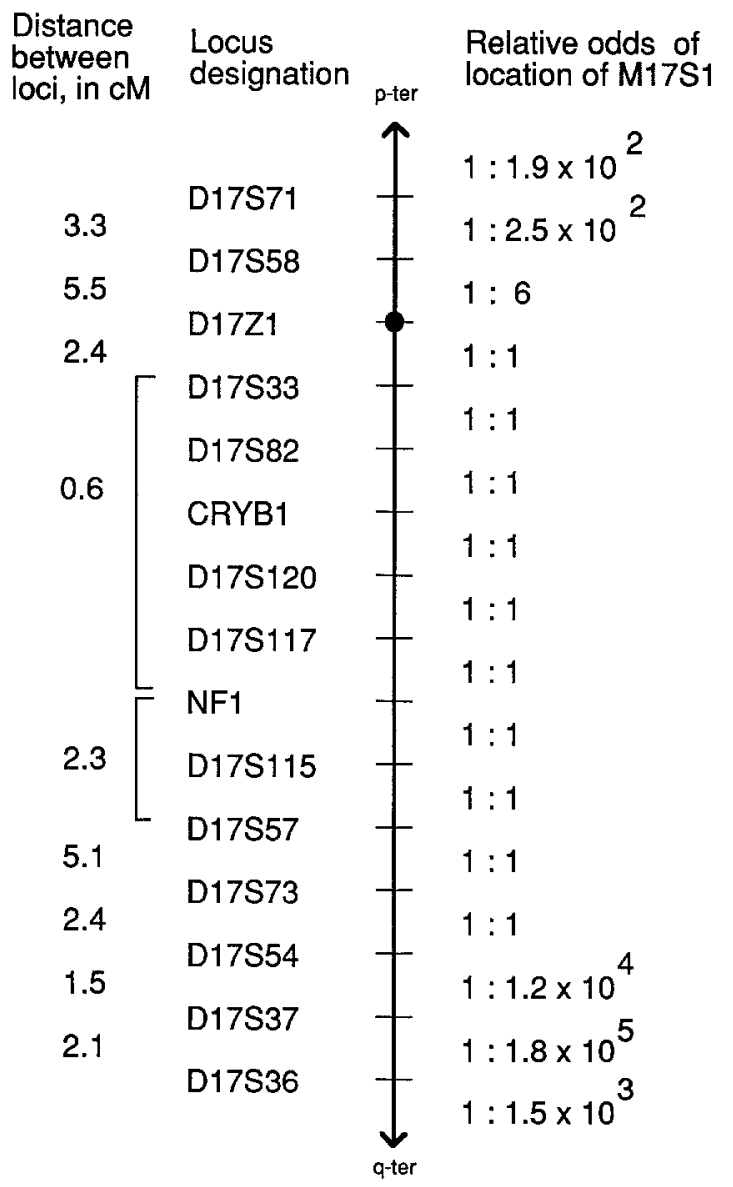

FIG. 2. Position of the M17S1 locus on the genetic map of chromosome 17. The relative odds, calculated from the likelihood values, in favor of placement of the M17S1 gene in a given locus interval are shown. Sex-averaged distances are given in cM (Goldgar et al., 1989). 
A

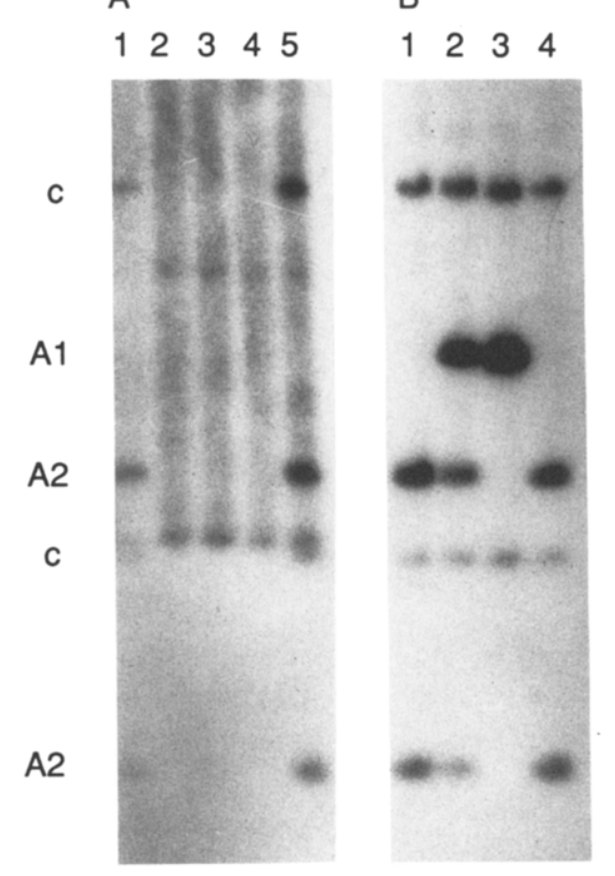

C $123 \quad 4$

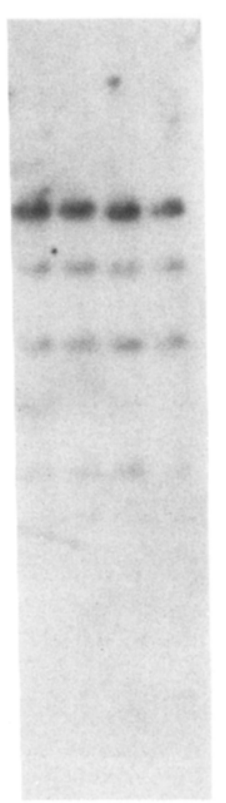

FIG. 3. Physical mapping of M17S1. Autoradiograms resulting from hybridization of the M17S1 cDNA pESA2 and L946 to a Southern membrane of $P s t I$-digested genomic and somatic cell hybrid DNA. Human-specific fragments are labeled for M17S1; A1 is the 2.1-kb allele, $\mathrm{A} 2$ is the 1.4- and $0.6-\mathrm{kb}$ allele, and $\mathrm{c}$ indicates the $3.1-$ and $1,1-\mathrm{kb}$ constant fragments. (A) $13 \mu \mathrm{g}$ DNA from murine and hybrid cell lines, hybridized to M17S1. Lane 1, MH22.6; lane 2, LMTk ${ }^{-}$; lane 3, DCR-1; lane 4, NF13; lane 5, SP3-10. (B) $4 \mu \mathrm{g}$ DNA from peripheral blood leukocytes of four unrelated individuals, hybridized to M17S1. Lanes 1, 2, and 3, unaffected control individuals; lane 4, NF1 deletion patient UWA106-3. The samples in A and $\mathbf{B}$ were coelectrophoresed, transferred, and hybridized on a single membrane; the photograph of the autoradiogram was cut apart to simplify presentation of the data. (C) The same section of membrane shown in $\mathbf{B}$, hybridized to L946. Arrowhead indicates the 2.4-kb band used in densitometry.

plays the maximum likelihood phase choice for ordered loci on the two chromosomes of each offspring, was used to detect loci involved in recombination events. Data for all loci involved in recombination events were checked for accuracy; all families have been screened for possible nonpaternities (Stephens et al., 1989).

\section{RESULTS}

\section{RFLP Revealed by M17S1}

To facilitate genetic mapping, we screened DNA from five unrelated individuals digested with 11 different restriction enzymes for an RFLP revealed by the M17S1 gene. DNA fragments of variant length were observed in the PstI-digested samples; no fragment size variations were observed in digests involving $B a m \mathrm{HI}, B g l \mathrm{II}, E c o \mathrm{RI}$, HindIII, Hinfl, HpaII, MspI, PvuII, TaqI, or RsaI (data not shown). The variant length PstI fragments were shown to represent the two alleles of a single locus by their segregation pattern in 20 multigenerational families; a representative result is shown in Fig. 1 . Allele 1 is $2.1 \mathrm{~kb}$ in length and allele 2 consists of two fragments,

1.4 and $0.6 \mathrm{~kb}$ in size. Allele frequencies, based on 134 chromosomes of unrelated Caucasian individuals, were 0.21 for allele 1 and 0.79 for allele 2 . The polymorphic information content (Botstein et al., 1980) was calculated at 0.27 .

\section{Genetic Mapping of the M17S1 Gene}

The segregation of alleles for the PstI RFLP of M17S1 and RFLPs for 6 other loci described under Materials and Methods were determined in the $18 \mathrm{NF} 1$-affected families. Pairwise lod scores between M17S1 and 5 of these loci, plus 8 loci from our previous studies and the NF1 phenotype (Stephens et al., 1987, 1989), are given in Table 1, in order of decreasing lod score. The pairwise lod scores, calculated under the hypothesis of equal recombination frequency in males and females, show that the M17S1 and NF1 genes are tightly linked giving a maximum lod score of 6.62 at a $\theta$ of 0.00 . Lod scores exceeding 3.0, significant evidence in favor of linkage, were also obtained for D17S57, D17S73, and D17S54 (Table 1). No recombination events were detected between M17S1 and either D17S57 or D17S73 (Table 1). Pairwise lod scores between M17S1 and 10 other loci were positive but not statistically significant (Table 1). Two-point lod scores for M17S1 and D17S82 are not shown since no meioses were jointly informative at both loci. Significant evidence in favor of excluding tight linkage between the most q-distal locus, D17S36, and M17S1 was obtained (Table 1). A lod score of -2.0 at $\theta=$ 0.009 excludes M17S1 from a location within approximately $1 \%$ recombination either side of the D17S36 locus.
A
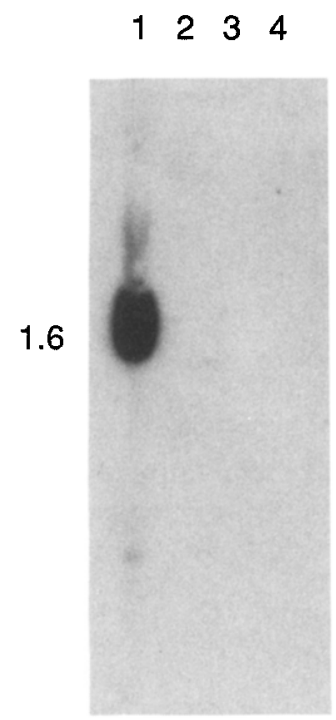

B

$\begin{array}{llll}1 & 2 & 3 & 4\end{array}$

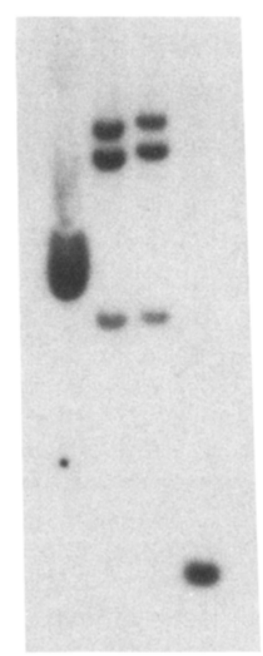

FIG. 4. Mapping of M17S1 on NF1-YACs. (A) autoradiogram resulting from hybridization of the M17S1 cDNA pESA2 to a Southern membrane of $E$ coRI-digested DNA from NF1-YAC-bearing yeast. Lane 1, molecular weight marker, size given in kb; lane 2, YAC D8F4; lane 3, YAC A113D7; lane 4, YAC A43A9. (B) Autoradiogram of the Southern membrane in $\mathbf{A}$ after rehybridization to the NF1 cDNAs GE2 and P5. 


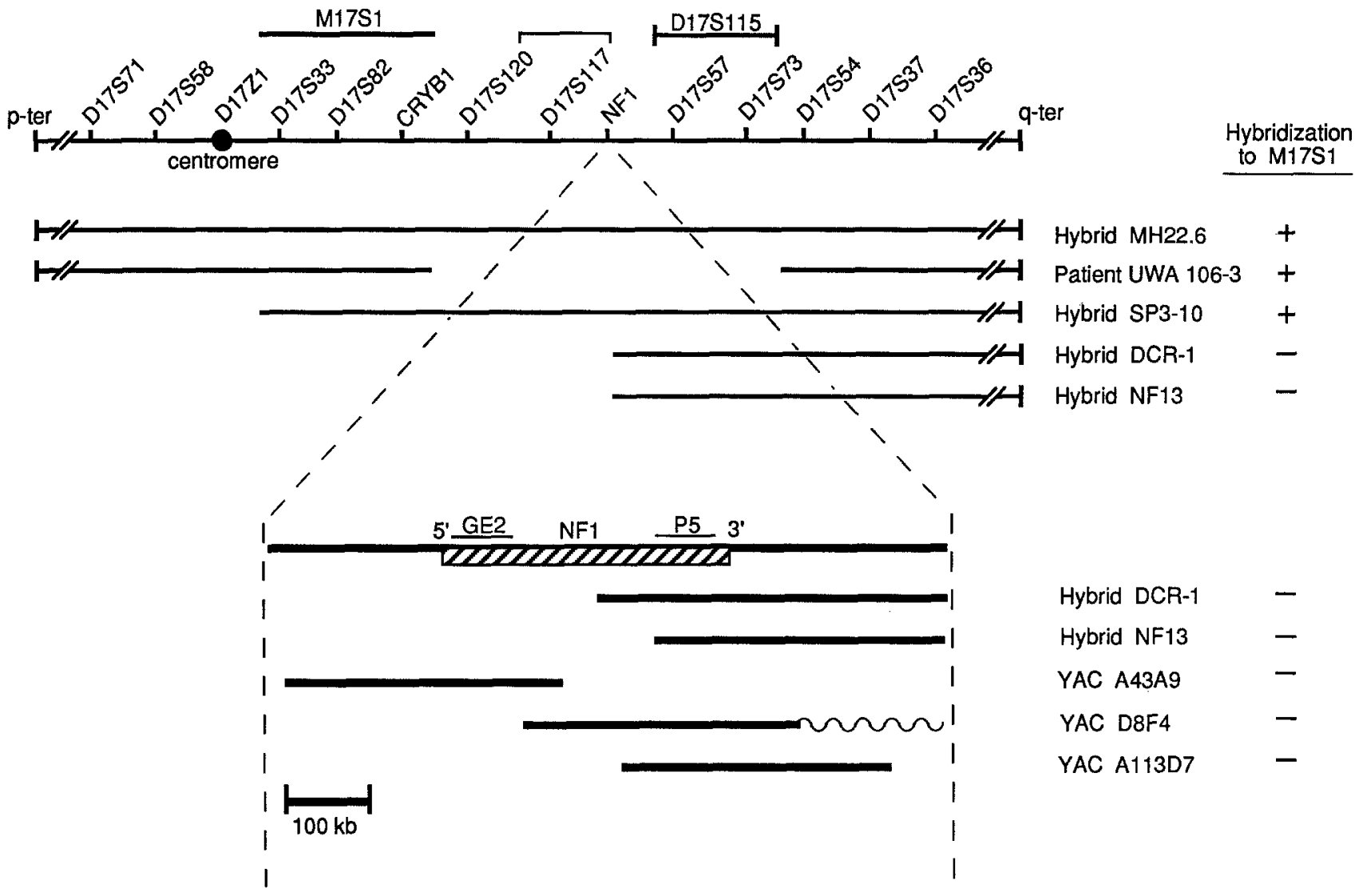

FIG. 5. Map of the chromosome 17 pericentromeric region. The upper line diagram shows the relative order of loci, including the NF1 gene (Stephens et al., 1987; Goldgar et al., 1989; Fain et al., 1989; O'Connell et al., 1989). Diagram is not drawn to scale; refer to Fig. 2 for genetic distances. Two ambiguities in locus order are indicated above the map; the order of D17S120 and D17S117 may be reversed and the position of D17S115 with respect to D17S57 and D17S73 is not known. Below the map, subchromosomal fragments present in the hybrid cell lines and the deletion patient UWA106-3 are indicated. The expanded region is a physical map of the NF1 gene, drawn to scale, showing the endpoints of chromosome 17 segments carried by the translocation hybrids DCR-1 and NF13 and the NF1-YACs. YAC D8F4 is chimeric; the wavy line represents human DNA from an unknown locus (Marchuk et al., 1992). The approximate positions of the NF1 cDNAs GE2 and P5 are indicated. +, Hybridization to M17S1 on Southern blot analysis; -, no significant hybridization to M17S1.

Multipoint genetic linkage analyses were performed to map the M17S1 gene relative to NF1 and other loci in the $17 q$ proximal region. Figure 2 summarizes the relative probability that M17S1 maps to any one of 10 interlocus intervals. Significant evidence in favor of excluding placement (relative odds $>1: 100$ ) of M17S1 outside of the interval bounded by D17S58 and D17S54 was obtained (Fig. 2).

\section{Physical Mapping of the M17S1 Gene}

Somatic cell hybrids carrying subchromosomal regions of human chromosome 17 were used to refine the location of the M17S1 gene. The locations of the breakpoint(s) carried by each hybrid are diagramed in Fig. 5 . All hybrid cell lines display fragments that comigrate with murine-specific fragments in the $\mathrm{LMTk}^{-}$murine cell line (Fig. 3A, lane 2). MH22.6, a human chromosome 17 hybrid (lane 1), displays the expected human-specific fragments of the M17S1 allele 2 and constant bands. While the two hybrids carrying derivatives of balanced translocations in the NF1 gene, DCR-1 (lane 3) and NF13 (lane 4), show no human-specific fragments,
M17S1 homologous bands were observed in the hybrid SP3-10 (lane 5). SP3-10 clearly has the two fragments of the M17S1 allele 2 and the constant bands. These data map the M17S1 gene to the region between the SP3-10 and DCR-1 breakpoints.

To determine whether the M17S1 gene was embedded within the NF1 gene, we hybridized the M17S1 cDNA to three overlapping NF1-YACs that together span the entire $>300 \mathrm{~kb}$ of the NF1 gene (Marchuk et al., 1992; Fig. 5). As shown in Fig. 4A, the NF1-YACs carried no fragments homologous to M17S1. The membrane was hybridized in the same bag as the membrane shown in Fig. 3 , demonstrating that the hybridization reaction was successful. To confirm the presence and integrity of NF1YAC DNA on the blot, it was stripped and simultaneously rehybridized to P5 and GE2, two NF1 cDNA fragments known to map within the YAC clones (Marchuk et al., 1992; Fig. 5). Figure 4B demonstrates that the quality of the Southern blot was sufficient to generate a detectable signal upon hybridization to a singlecopy gene probe. In a separate experiment, no detectable hybridization was observed between the M17S1 cDNA and DNA from non-YAC-bearing yeast (data not 
shown). These data show unambiguously that the M17S1 gene is not embedded within the NF1 gene.

To further define the location of M17S1 in the region centromeric to NF1, it was mapped on UWA106-3, an NF1 patient that we have recently identified with an extensive deletion encompassing an entire NF1 allele (Materials and Methods; Kayes et al., 1992; Fig. 5). The M17S1 alleles of UWA106-3 are shown in Fig. 3B in comparison to three unrelated, unaffected individuals displaying the three possible allele combinations at the locus. Lane 4 shows that UWA106-3 is either homozygous or hemizygous for allele 2 of M17S1. The copy number of M17S1 in DNA from peripheral blood for patient UWA106-3 was determined by densitometry of the autoradiograms in Figs. $3 \mathrm{~B}$ and $3 \mathrm{C}$ as described under Materials and Methods. The M17S1/L946 density ratios were equivalent for the control individual and UWA1063: 0.807 and 0.779 , respectively. These data show that the deletion carried by UWA106-3 does not include the M17S1 gene.

\section{DISCUSSION}

Using both genetic and physical breakpoints, we have mapped the gene for a novel epidermal antigen, M17S1, to a small $\mathrm{q}$-proximal interval of chromosome 17 . Genetic mapping was facilitated by the identification and characterization of a two-allele M17S1 polymorphism with a PIC of 0.27 revealed by the restriction enzyme PstI (Fig. 1). Ten other restriction enzymes tested did not reveal any apparent polymorphism with the M17S1 cDNA, pESA2.

As predicted from the in situ hybridization data mapping M17S1 to chromosome bands 17q11-q12 (Schroeder et al., 1991), lod score analyses demonstrated that M17S1 was linked to loci in this region. The genotype for the M17S1 PstI polymorphism and the polymorphisms for seven additional probe/enzyme systems were determined for individuals of 18 NF1 families. These families were chosen from our large repository of NF1 families because they would provide the maximum information; each family contained individuals with previously defined recombination events in the chromosome 17 pericentromeric region (Stephens et al., 1989). Significant evidence in favor of tight linkage between M17S1 and four pericentromeric loci was obtained: NF1, D17S57, D17S73, and D17S54 (Table 1).

Multipoint linkage analyses were performed to map the location of the M17S1 gene relative to other pericentromeric loci. Significant evidence in favor of placement of the M17S1 gene between the loci D17S58 and D17S54 (Fig. 2), an interval known to contain the NF1 gene, was obtained. These data, in addition to the in situ data mapping M17S1 to chromosome band 17q11-q12 (Schroeder et al., 1991), map the M17S1 gene to a 13-cM interval between the centromere (D17Z1) and D17S54 (Figs. 2 and 5).

Since finer genetic mapping of $\mathrm{M} 17 \mathrm{~S} 1$ would require a large number of meioses or a more informative RFLP, we chose to use physical breakpoints to further localize the gene. The M17S1 gene was not found in two hybrid cell lines (DCR-1 and NF13) carrying derivative chromosomes 17 with breakpoints in the NF1 gene (Figs. 3 and 5). These data narrowed the interval containing the M17S1 gene to a location between the centromere (D17Z1) and the DCR-1 breakpoint near the 3 ' end of the NF1 gene (Fig. 5). The presence of M17S1 homologous sequences in the hybrid SP3-10, which carries the entire NF1 gene plus additional centromeric-proximal sequences (Fig. 5, van Tuinen et al., 1987; Fain et al., 1989; Fountain et al., 1989), suggested that the M17S1 gene was either near the $5^{\prime}$ end, or embedded within, the NF1 gene.

To determine whether the M17S1 gene was embedded within the NF1 gene, we hybridized the pESA2 cDNA to three NF1-YACs that form a contig encompassing the entire NF1 gene (Marchuk et al., 1992). As shown in Fig. 4 and summarized in Fig. 5, M17S1 homologous sequences were not detected in any of the YACs. These data demonstrate unambiguously that the M17S1 gene is not embedded within the NF1 gene. The possibility that M17S1 may map adjacent to the $5^{\prime}$ end of the NF1 gene was also excluded; YAC A43A9 carries approximately $180 \mathrm{~kb}$ of DNA upstream of the $5^{\prime}$ end of the NF1 gene (Marchuk et al., 1992; Fig. 5). These data narrowed the interval carrying the M17S1 gene to a location between the hybrid SP3-10 breakpoint and $180 \mathrm{~kb}$ centromere-proximal to the NF1 gene (Fig. 5).

Additional data mapped the M17S1 gene between the SP3-10 translocation breakpoint and the deletion breakpoint of individual UWA106-3. UWA106-3 is an NF1 patient carrying a large deletion encompassing an entire NF1 allele and contiguous genetic material (Kayes et al., 1992; Fig. 5). Densitometric analysis showed that UWA106-3 had two copies of the M17S1 gene (Fig. 3), proving that M17S1 was located outside this deletion.

In our previous study, the proximal extent of the deletion in UWA106-3 had not been established unambiguously with respect to the $5^{\prime}$ end of the NF1 gene (Kayes et al., 1992). D17S120, the most centromeric-proximal locus deleted in UWA106-3, was thought to map 5 to the NF1 gene since a microcell fusion breakpoint separated the two, but conclusive evidence was not available (Fain et al., 1989). The NF1-YAC contig clones provided the opportunity to precisely define the proximal deletion breakpoint of UWA106-3. Southern blot hybridization of the YACs proved that D17S120 is not within the NF1 gene (data not shown). Therefore, the UWA106-3 deletion breakpoint lies a minimum of $180 \mathrm{~kb}$ centromeric to the NF1 promotor. These data confirm our previous conclusion that the NF1 phenotype appears to be the result of inactivation of one allele, rather than by the action of an abnormal neurofibromin protein product (Kayes et al., 1992) and provide a well-defined breakpoint for mapping other loci in the $17 q$ centromereproximal region.

The interval between the SP3-10 translocation and 
UWA106-3 deletion breakpoints contains at least one additional gene, $\beta$-crystallin, and the anonymous loci D17S33 (pHHH202), D17S82 (pTH17.19), and D17S116 (pVAW211) (Fountain et al., 1989; Fain et al., 1989). The estimated minimum genetic distance of the interval is $0.6 \mathrm{cM}$, the sex-averaged genetic distance between NF1 and D17S33 (Goldgar et al., 1989). pHHH202, the probe for locus D17S33, detects and lies $<220 \mathrm{~kb}$ distal to the SP3-10 breakpoint (Fountain et al., 1989).

Although the M17S1 gene is tightly linked to, and physically near the NF1 gene, the results of this study show that it is not embedded within the NF1 gene, nor is it physically close enough to likely be disrupted by the majority of mutations causing the NF1 disorder. Only a large deletion or complex chromosomal rearrangement could involve the M17S1 gene, located $>180 \mathrm{~kb}$ proximal to the NF1 gene; such rearrangements of the NF1 gene appear to be uncommon (Upadhyaya et al., 1990). Therefore, defects in M17S1 expression probably do not contribute to the skin manifestations or variable expressivity of NF1.

\section{ACKNOWLEDGMENTS}

We thank Wendy Raskind and Laura Steinmann for their densitometry expertise. This research was supported by the National Neurofibromatosis Foundation, Inc., Stephen Walker Memorial Award (K.S.), the University of Washington Graduate School Research Fund (K.S.), and, in part, by USPHS RD36546 (M.D.) and USPHS NS23410 (F.S.C.). Fellowship support for L.M.K. was provided by The Cancer Research Foundation of America or USPHS T32 GM07454. W.S. was the recipient of fellowship and career development support from the Dermatology Foundation sponsored by Roche Pharmaceuticals, Squibb Laboratories, and the Society for Investigative Dermatology. F.S.C. is an investigator of the Howard Hughes Medical Institute.

\section{REFERENCES}

Barker, D., Green, P., Knowlton, R., Schumm, J., Lander, E., Oliphant, A., Willard, H., Akots, G., Brown, V., Gravius, T., Helms, C., Nelson, C., Parker, C., Rediker, K., Rising, M., Watt, D., Weiffenbach, B., and Donis-Keller, H. (1987). Genetic linkage map of human chromosome 7 with 63 DNA markers. Proc. Natl. Acad. Sci. USA 84: 8006-8010.

Bell, G. I., Karam, J. H., and Rutter, W. J. (1981). Polymorphic DNA region adjacent to the $5^{\prime}$ end of the human insulin gene. Proc. Natl. Acad. Sci. USA 78: 5759-5763.

Botstein, D., White, R., Skolnick, M., and Davis, R. (1980). Construction of a genetic linkage map using restriction fragment length polymorphisms. Am. J. Hum. Genet. 32: 314-31.

Buchberg, A. M., Bidigian, H. G., Jenkins, N. A., and Copeland, N. G. (1990). Evi-2, a common integration site involved in murine myeloid leukemogenesis. Mol. Cell. Biol. 10: 4658-4666.

Cawthon, R. M., O'Connell, P., Buchberg, A. M., Viskochil, D., Weiss, R. B., Culver, M., Stevens, J., Jenkins, N. A., Copeland, N. G., and White, R. (1990a). Identification and characterization of transcripts from the neurofibromatosis 1 region: The sequence and genomic structure of EVI2 and mapping of other transcripts. Genomics 7: 555-565.

Cawthon, R. M., Weiss, R., Xu, G., Viskochil, D., Culver, M., Stevens, J., Robertson, M., Dunn, D., Gesteland, R., O'Connell, P., and White, R. (1990b). A major segment of the neurofibromatosis type 1 gene: cDNA sequence, genomic structure, and point mutations. Cell 62: $193-201$.

Cawthon, R. M., Andersen, L. B., Buchberg, A. M., Xu, G., O'Connell, P., Viskochil, D., Weiss, R. B., Wallace, M. R., Marchuk, D. A., Culver, M., Stevens, J., Jenkins, N. A., Copeland, N. G., Collins, F. S., and White, R. (1991). cDNA sequence and genomic structure of EVI2B, a gene lying within an intron of the neurofibromatosis type 1 gene. Genomics 9: 446-460.

Crowe, F. W., Schull, W. T., and Neel, J. V. (1956). "A Clinical, Pathological, and Genetic Study of Multiple Neurofibromatosis," Thomas, Springfield, IL.

Donis-Keller, H., Green, P., Helms, C., Cartinhour, S., Weiffenbach, B., Stephens, K., Keith, T. P., Bowden, D. W., Smith, D. R., Lander, E. S., Botstein, D., Akots, G., Rediker, D. S., Gravius, T., Brown, V. A., Rising, M. B., Parker, C., Powers, J., Watt, D. E., Kauffman, E. R., Bricker, A., Phipps, P., Muller-Kahle, H., Fulton, T. R., Ng, S., Schumm, J. W., Braman, J. C., Knowlton, R. G., Barker, D. F., Crooks, S. M., Lincoln, S. E., Daly, M. J., and Abrahamson, J. (1987). A genetic linkage map of the human genome. Cell 51: 319 337.

Fain, P. R., Goldgar, D. E., Wallace, M. R., Collins, F. S., Wright, E., Nguyen, K., and Barker, D. F. (1989). Refined physical and genetic mapping of the NF1 region on chromosome 17. Am. J. Hum. Genet. 45: $721-728$.

Feinberg, A., and Vogelstein, B. (1983). A technique for radiolabeling DNA restriction endonuclease fragments to high specific activity. Anal. Biochem. 132: 6-13.

Fine, J.-D., Bauer, E. A., Briggaman, R. A., Carter, D. M., Eady, R. A. J., Esterly, N. B., Holbrook, K. A., Hurwitz, S., Johnson, L., Lin, A., Pearson, R., and Sybert, V. P. (1991). Revised clinical and laboratory criteria for subtypes of inherited epidermolysis bullosa. J. Am. Acad. Dermatol. 24: 119-135.

Fountain, J. W., Wallace, M. R., Brereton, A. M., O'Connell, P., White, R., Rich, D. C., Ledbetter, D. H., Leach, R. J., Fournier, R. E. K., Menon, A. G., Gusella, J. F., Barker, D., Stephens, K., and Collins, F. (1989). Physical mapping of the von Recklinghausen neurofibromatosis region on chromosome 17. Am. J. Hum. Genet. 44: 58-67.

Fuchs, E. (1990). Epidermal differentiation. Curr. Opin. Cell. Biol. 2: 1028-1035.

Goldgar, D. E., Green, P., Parry, D. M., and Mulvihill, J. J. (1989). Multipoint linkage analysis in neurofibromatosis type 1: An international collaboration. Am. J. Hum. Genet. 44: 6-12.

Huson, S. M., Compston, D. A. S., and Harper, P. S. (1989). A genetic study of von Recklinghausen neurofibromatosis in south east Wales. II. Guidelines for genetic counseling. J. Med. Genet. 26: $712-721$.

Kayes, L. M., Riccardi, V. M., Burke, W., Bennett, R. L., and Stephens, K. (1992). Large de novo DNA deletion in a patient with sporadic neurofibromatosis 1 , mental retardation, and dysmorphism. J. Med. Genet., in press.

Ledbetter, D. H., Rich, D. C., O’Connell, P., Leppert, M., and Carey, J. C. (1989). Precise localization of NF1 to $17 q 11.2$ by balanced translocation. Am. J. Hum. Genet. 44: 20-24.

Marchuk, D. A., Saulino, A. M., Tavakkol, R., Swaroop, M., Wallace, M. R., Andersen, L. B., Mitchell, A. L., Gutmann, D. H., Boguski, M., and Collins, F. S. (1991). cDNA cloning of the type 1 neurofibromatosis gene: Complete sequence of the NF1 gene product. Genomics 11: 931-940.

Marchuk, D. A., Tavakkol, R., Wallace, M. R., Brownstein, B. H., Taillon-Miller, P., Fong, C-T., Legius, E., Anderson, L. B., Glover, T. W., and Collins, F. S. (1992). A yeast artificial chromosome contig encompassing the type 1 neurofibromatosis gene. Genomics 13: $672-680$.

Menon, A. G., Ledbetter, D. H., Rich, D. C., Seizinger, B. R., Rouleau, G. A., Michels, V. F., Schmidt, M. A., Dewald, G., Dalla'Torre, C. M., Haines, J. L., and Gusella, J. F. (1989). Characterization of a trans- 
location within the von Recklinghausen neurofibromatosis region of chromosome 17. Genomics 5: 245-249.

Mikol, D. D., and Stefansson, K. (1988). A phosphatidylinositollinked peanut agglutinin-binding glycoprotein in central nervous system myelin and on oligodendrocytes. J. Cell. Biol. 106: 12731279.

Negi, M., Lane, A., McCoon, P. E., Fairley, J. A., and Goldsmith, L. A. (1986). Monoclonal antibody to a $35 \mathrm{kD}$ epidermal protein induces cell detachment. J. Invest. Dermatol. 86: 634-637.

O'Connell, P., Leach, R. J., Ledbetter, D. H., Cawthon, R. M., Culver, M., Eldridge, J. R., Frej, A.-K., Holm, T. R., Wolff, E., Thayer, M. J., Schafer, A. J., Fountain, J. W., Wallace, M. R., Collins, F. S., Skolnick, M. H., Rich, D. C., Fournier, R. E. K., Baty, B. J., Carey, J. C., Leppert, M. F., Lathrop, G. M., Lalouel, J.-M., and White, R. (1989). Fine structure DNA mapping studies of the chromosomal region harboring the genetic defect in neurofibromatosis type 1. Am. J. Hum. Genet. 44: 51-57.

O'Connell, P., Viskochil, D., Buchberg, A. M., Fountain, J., Cawthon, R. M., Culver, M., Stevens, J., Rich, D. C., Ledbetter, D. H., Wallace, M., Carey, J. C., Jenkins, N. A., Copeland, N. G., Collins, F. S., and White, R. (1990). The human homology of murine Evi-2 lies between two von Recklinghausen neurofibromatosis translocations. Genomics 7: 547-554.

Riccardi, V. M. (1992). "Neurofibromatosis: Phenotype, Natural History, and Pathogenesis," 2nd ed., Johns Hopkins Univ. Press, Baltimore, MD.

Rubenstein, A. E., and Korf, B. R. (1990). "Neurofibromatosis: A Handbook for Patients, Families, and Health-Care Professionals," Thieme Medical Publishers, New York.

Schmidt, M. A., Michels, V. V., and Dewald, G. W. (1987). Cases of neurofibromatosis with rearrangements of chromosome 17 involving band q11.2. Am. J. Med. Genet. 28: 771-777.

Schroeder, W. T., Siciliano, M. J., Stewart-Galetka, S. L., and Duvic, M. (1991). The human gene for an epidermal surface antigen is located at 17q11-12. Genomics 11: 481-482.

Schumm, J. W., Knowlton, R. G., Braman, J. C., Barker, D. F., Botstein, D., Akots, G., Brown, V. A., Gravius, T. C., Helms, C., Hsiao, K., Rediker, K., Thurston, J. G., and Donis-Keller, H. (1988). Identification of more than 500 RFLPs by screening random genomic clones. Am. J. Hum. Genet. 42: 143-159.

Sheer, D., Hiorns, L. R., Stanley, F., Goodfellow, P. N., Swallow, D. M., Povey, S., Heisterdamp, N., Groffen, J., Stephenson, J. R., and Solomon, E. (1983). Genetic analysis of the 15:17 chromosome translocation associated with acute promyelocytic leukemia. Proc. Natl. Acad. Sci. USA 80: 5007-5011.
Sheer, D., Sheppard, D. M., leBeau, M., Rowley, J. D., San Roman, C., and Solomon, E. (1985). Localization of the oncogene c-erbA1 immediately proximal to the acute promyelocytic leukaemia breakpoint on chromosome 17. Ann. Hum. Genet. 49: 167-171.

Sherman, F., Fink, G. R., and Hicks, J. B. (1986). "Laboratory Course Manual for Methods in Yeast Genetics," Cold Spring Harbor Laboratory Press, Cold Spring Harbor, NY.

Stephens, K., Riccardi, V. M., Rising, M., Ng, S., Green, P., Collins, F. S., Rediker, K. D., Powers, J. A., Parker, C., and Donis-Keller, H. (1987). Linkage studies with chromosome 17 DNA markers in 45 neurofibromatosis 1 families. Genomics 1: 353-357.

Stephens, K., Green, P., Riccardi, V. M., Ng, S., Rising, M., Barker, D., Darby, J. K., Falls, K. M., Collins, F. S., Willard, H. F., and Donis-Keller, H. (1989). Genetic analysis of eight loci tightly linked to neurofibromatosis 1. Am. J. Hum. Genet. 44: 13-19.

Stumpf, S., Alksne, J. F., Annegers, J. F., Brown, S. S., Conneally, P. M., Housman, D., Leppert, M. F., Miller, J. P., Moss, M. L., Pileggi, A. J., Rapin, I., Strohman, R. C., Swanson, L. W., and Zimmerman, A. (1988). Neurofibromatosis Conference Statement. Arch. Neurol. 45: 575-578.

Upadhyaya, M., Cheryson, A., Broadhead, W., Fryer, A., Shaw, D. J., Huson, S., Wallace, M. R., Andersen, L. B., Marchuk, D. A., Viskochil, D., Black, D., O'Connell, P., Collins, F. S., and Harper, P. S. (1990). A $90 \mathrm{~kb}$ DNA deletion associated with neurofibromatosis type 1. J. Med. Genet. 27: 738-741.

van Tuinen, P., Rich, D. C., Summers, K. M., and Ledbetter, D. H. (1987). Regional mapping panel for human chromosome 17: Application to neurofibromatosis type 1. Genomics 1: $374-381$.

Viskochil, D., Cawthon, R., O'Connell, P., Xu, G., Stevens, J., Culver, M., Carey, J., and White, R. (1991). The gene encoding the oligodendrocyte-myelin glycoprotein is embedded within the neurofibromatosis type 1 gene. Mol. Cell. Biol. 11: 906-912.

Wallace, M. R., Marchuk, D. A., Anderson, L. B., Letcher, R., Odeh, H. M., Saulino, A. M., Fountain, J. W., Brereton, A., Nicholson, J., Mitchell, A. L., Brownstein, B. H., and Collins, F. S. (1990). Type 1 neurofibromatosis gene: Identification of a large transcript disrupted in three NF1 patients. Science 249: 181-186.

Wallace, M. R., Andersen, L. B., Saulino, A. M., Gregory, P. E., Glover, T. W., and Collins, F. S. (1991). A de novo Alu insertion results in neurofibromatosis type 1. Nature 353: 864-866.

White, R., Nakamura, Y., O'Connell, P., Leppert, M., Lalouel, J.-M. Barker, D., Goldgar, D., Skolnick, M., Carey, J., Wallis, C. E., Slater, C. P., Mathew, C., and Ponder, B. (1987). Tightly linked markers for the neurofibromatosis type 1 gene. Genomics 1: 364367. 